\title{
TAXONOMIC NOTES ON THE GENUS EUODYNERUS DALLA TORRE (HYMENOPTERA: VESPIDAE: EUMENINAE) FROM NORTHERN VIETNAM
}

\author{
Dang Thi Hoa ${ }^{1}$, Nguyen Thi Phuong Lien ${ }^{{ }^{*}}$, Jun-ichi Kojima ${ }^{2}$ \\ ${ }^{1}$ Institute of Ecology and Biological Resources, VAST, *phuonglientit@gmail.com \\ ${ }^{2}$ Ibaraki University, Japan
}

\begin{abstract}
A taxonomic study of the genus Euodynerus Dalla Torre from Northern Vietnam is reported. The following four forms included in three species were recorded: E. dantici violaceipennis Giordani Soika, E. nipanicus nipanicus (von Schulthess), E. nipanicus tonkinensis Giordani Soika and E. trilobus (Fabricius). Of these, E. dantici violaceipennis and E. nipanicus nipanicus were newly recorded for Vietnam. Keys to species and subspecies are presented and records of their distribution in Northern Vietnam are also provided. This is the first result on the taxonomy of the genus in Vietnam, and the distribution records is an important contribution to the study on the distribution pattern of the species in the genus in Asia.
\end{abstract}

Keywords: Vespidae, Eumeninae, Euodynerus, new records, Northern Vietnam.

\section{INTRODUCTION}

The genus Euodynerus Dalla Torre comprises solitary eumenine wasps that mostly nest in preformed borings in wood, but a few burrow in soil, make mud nests, or utilize abandoned nests of mud daubers. The members of this genus are distinguished from those of related genera, such as Anterhynchium de Saussure and Pseudepipona de Saussure by the metanotum with a row of teeth at the posterior margin, and two sharp teeth on the upper part of the propodeum, behind the metanotum.

The genus is divided into three subgenera: Euodynerus Dalla Torre, Incolepipona Giordani Soika and Pareuodynerus Blüthgen [3]. More than 100 species of this genus have been recognized worldwide and 15 species are known to occur in Oriental region through unrelated studies on a national or regional basis $[8,3,5,6]$.

In Vietnam, Euodynerus nipanicus tonkinensis Giordani Soika and Euodynerus trilobus (Fabricius) were recorded by Giordani Soika (1994) [3]. In this paper, based on specimens deposited in the Institute of Ecology and Biological Resources (IEBR), taxonomic notes on the genus Euodynerus from northern Vietnam are presented, and keys to species and subspecies are also provided.

\section{MATERIALS AND METHODS}

The specimens examined in the present study are those deposited in the collections of the Institute of Ecology and Biological Resources (IEBR), Hanoi, Vietnam. Observations of morphological and color characters were made on the pinned and dried specimens under a stereoscopic dissecting microscope. All figures were made with aid of a drawing tube attached to the microscope. Terminology follows Yamane (1990) [8].

Collector is abbreviated as follows: ISD-c, staff members of the Insect Systematic Department; IED-c, staff members of the Insect Ecology Department (IEBR).

\section{RESULTS AND DISCUSSION}

Key to vietnamese species of the genus Euodynerus

The present key is applicable to both females and males unless the sex is specified.

1. Apical margin of clypeus emarginate medially, with two blunt teeth (figs 1- 3). Male antennal flagellomere II-VII not thickened apically (fig. 6). Dorsolateral part of propodeum well 
developed, produced into two sharp teeth at top. Clypeal punctures dense and round. Tegulae



- Apical margin of clypeus truncate (figs 4, 5) (slightly emarginate in some males). Male antennal flagellomere II-VII thickened apically (fig. 7). Dorsolateral part of propodeum less developed, forming two short and thick teeth at top. Clypeal punctures dense and elongate, often united to form longitudinal stripes. Tegulae with dense and coarse puncture. Euodyneruus dantici (Rossi)

2. Vertex with distinct three tubercles in ocellar region (one situated just behind anterior ocellus and apically bifid, the others two inside posterior ocelli). Male clypeus much longer than wide $(1,25: 1)$ (fig. 3) Euodynerus trilobus (Fabricius)

- Vertex without tubercles in ocellar region. Male clypeus slightly longer than wide $(1,1: 1)$ (fig. 2). Euodynerus nipanicus (von Schulthess)

\section{Key to the vietnamese subspecies of Euodynerus nipanicus (females)}

1. Clypeus black, basal margin rarely with a narrow yellow band. Scutellum and mesepisternum entirely black. Tibia of all legs black. E. nipanicus nipanicus (von Schulthess)

- Clypeus nearly entirely yellow, or black with a large basal yellow band. Scutellum black with yellow spot on each side. Mesepisternum black with a large yellow scrobal spot. Tibia of all legs ferruginous E.nipanicus tonkinensis (Giordani Soika)

\section{Euodynerus dantici violaceipennis Giordani Soika, 1973 (Figs 4, 5, 8, 9, 10)}

This subspecies has been recorded in China, Taiwan, Korea and Japan [1, 3, 4, 7, 8]. This is the first record of Euodynerus dantici (Rossi) for Vietnam.

Material examined: Cao Bang: 2 males, Thanh Cong, Nguyen Binh, $1000 \mathrm{~m}$, 8.VIII.2012, J. Kojima, H. Nugroho \& IED-c; Lao Cai: 1 male, Bac Ha, 26.VI.2008, L.T.P. Nguyen \& H.P. Pham; Son La: 1 female, Muong La, 660m, 25.VIII.2009, L.T.P. Nguyen, H.P. Pham \& J. Kojima.

There are two color forms in four specimens of $E$. dantici from Vietnam. One female from Muong La, Son La and one male from Bac Ha, Lao Cai have the mesepisternum entirely black, the metasomal terga I-III (in female) and I-IV (in male) with the apical margin colored yellow, while the two males from Nguyen Binh, Cao Bang have the black mesepisternum with a large yellow scrobal spot and the metasomal terga I-V with yellow apical margins. The male from Lao Cai has the clypeus with truncate apical margin, but the two males from Cao Bang have the clypeus with the apical margin slighty emarginate medially.

\section{Euodynerus nipanicus nipanicus (von Schulthess, 1908) (Fig. 12)}

This subspecies is known to occur in China, Korea, Japan and questionably Thailand [2, 5, $8]$ and is newly recorded from Vietnam.

Material examined: Dien Bien: 1 female, Muong Nhe, 23.VII.2009, L.T.P. Nguyen, P.H. Pham \& J. Kojima; Son La: 1 female, Thuan Chau, 1500 m, 03.VI.2009, P.H. Pham.

\section{Euodynerus nipanicus tonkinensis Giordani Soika, 1973 (Figs 1, 2, 13)}

This subspecies has been recorded only in Vietnam (Hoa Binh) and China [1,3]. In this study, the subspecies is also recorded from Lao Cai and Hanoi.

Material examined: Lao Cai: 1 male, Nam Cuong, 11.VI.2004, L.D. Khuat; Phu Tho: 1 female, Tan Son, 19.V.2011, P.H. Pham; Hoa Binh: 1 female, Mai Chau, 600 m, 10.vi.2008, L.T.P. Nguyen \& P.H. Pham; Yen Thuy (1 male, 2.V.2002, T.V. Hoang; 1 female, 1.V.2002, T.V. Hoang; 1 female, Malaise trap, 20.IV.2003); Hanoi: 1 female, Thach That, Malaise trap, 15-25.VIII.2002; 1 male, Thach That, Malaise trap, 6-16.iv.2002; 1 female, Long Bien, 21.VII.2010, H.T. Dang. 
Euodynerus trilobus (Fabricius, 1787) (Figs 7, 11)

This species has been recorded from Mauritius, China, Malaysia, Indonesia, Taiwan and Japan. Giordani Soika (1994) [3] recorded this species in Vietnam, but he did not mention the exact locality. The present study gives the distribution records of this species in several provinces in Vietnam.

Material examined: Phu Tho: 1 male, Tan Son, 19.V.2011, P.H. Pham; 1 male, Tan Son,
3.X.2011, L.D. Khuat; Vinh Phuc: 1 female, Me Linh, 07.VI.2001, L.X. Truong; Hanoi: 1 female, Long Bien, 16.VIII.2011, H.T. Dang; 1 male, Long Bien, 26.VII.2011, H.T. Dang; Bac Giang: 1 female \& 1 male, An Lac, Son Dong, 10.VIII.2012, J. Kojima, H. Nugroho and IEDc; Hoa Binh: Yen Thuy (1 male, 14.VII.2000, L.X. Truong, 1 female, 15.VII.2000, L.X. Truong; 1 male, 2.V.2002, T.V. Hoang); Ha Tinh: 1 male, Huong Khe, 22.V.2008, L.D. Khuat.

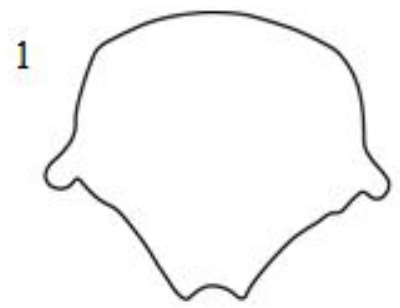

2

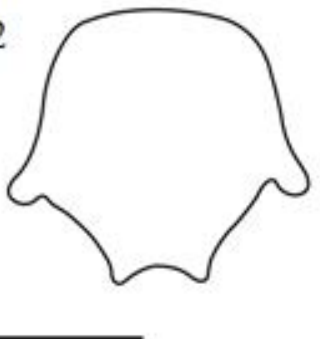

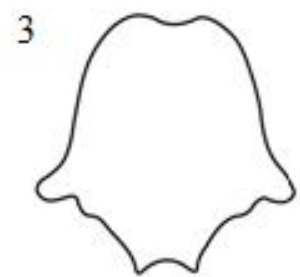


7

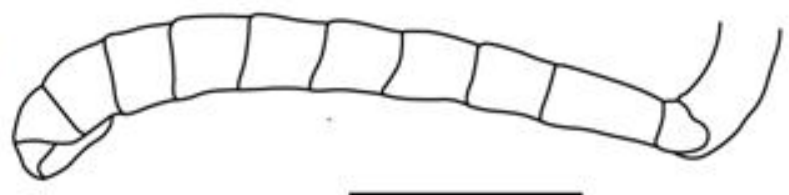

Figs. 1-7. Genus Euodynerus. 1-5. Clypeus in frontal view: 1, 2. E. nipanicus tonkinensis (1, female; 2, male); 3. E. trilobus (male); 4, 5. E. dantici (4, female; 5, male). 6-7. Left antenna: 6. E. dantici (male); 7. E. trilobus (male). Scale $1 \mathrm{~mm}$. 



Figs. 8-13. Genus Euodynerus. 8-10. E. dantici violaceipennis (8, 9, female; 10, male);

11. E. trilobus, female; 12. E. nipanicus nipanicus, female; 13. E. nipanicus tonkinensis, female.

Acknowledgements: We thank Dr. James M. Carpenter for his comments on an earlier draft of the manuscript. This research was funded by the Vietnam National Foundation for Science and Technology Development (NAFOSTED) under the grant number 106.12-2011.30.

\section{REFERENCES}

1. Giordani Soika A., 1973. Notulae vespidologicae 35. Descrizione di nuovi 
eumenidi. Bollettino del Museo Civico di Storia Naturale di Venezia, 24: 97-131.

2. Giordani Soika A., 1976. Vespid ed eumenidi raccolti in Corea (Hymenoptera). Annales Historico-Naturales Musei Nationalis Hangarici, 68: 287-293.

3. Giordani Soika A., 1994. Ricerche sistematiche su alcuni generi di Eumenidi della Regione Orientale e della Papuasia (Hymenoptera, Vespoidea). Annali del Museo Civico di Storia Naturale "G. Doria", 90: 1-348.

4. Gusenleitner J., 1979. Bemerkenswertes uber Faltenwespen 7. Nachrichtenblatt Bayer. Entomol. 28: 60-63.

5. Gusenleitner J., 1988. Über Faltenwespen aus dem asiatischen Raum (Hymenoptera, Eumenidae, Masaridae). Linzer Biologische Beitrage, 30(2): 503-513.

6. Gusenleitner J., 2008. Bemerkenswerte Faltenwespen-Funde aus der orientalischen Region Teil 4. Mit einem Anhang über eine Art aus Neu-Kaledonien (Hymenoptera: Vespidae, Eumeninae). Linzer Biologische Beitrage, 40(2): 1495-1503.

7. Vecht J. van der and Fischer F. C. J, 1972. Palearctic Eumenidae. Hymenoptrum Catalogus (nova editio), 8: 1-199.

8. Yamane S., 1990. A revision of the Japanese Eumenidae (Hymenoptera, Vespoidea). Insecta Matsumurana (New Series), 43: 1-189.

\title{
VỀ PHÂN LOAI GIỐNG EUODYNERUS DALLA TORRE (HYMENOPTERA: VESPIDAE: EUMENINAE) Ở MIỀN BĂC VIỆT NAM
}

\author{
Đặng Thị Hoa ${ }^{1}$, Nguyễn Thị Phương Liên ${ }^{1}$, Junichi Kojima ${ }^{2}$ \\ ${ }^{1}$ Viện Sinh thái và Tài nguyên sinh vật, Viện Khoa học và Công nghệ Việt Nam \\ ${ }^{2}$ Đại học Ibaraki, Nhật Bản
}

\section{TÓM TẮT}

Bài báo trình bày kết quả nghiên cứu về phân loại của giống Euodynerus Dalla Torre ở miền Bắc Việt Nam. Giống Euodynerus Dalla Torre gồm ba loài là E. dantici violaceipennis Giordani Soika, $E$. nipanicus và $E$. trilobus (Fabricius) được ghi nhận. Trong đó, hai phân loài $E$. dantici violaceipennis và E. nipanicus nipanicus lần đầu được ghi nhận ở Việt Nam. Khóa định loại đến loài thuộc giống Euodynerus Dalla Torre dựa trên đặc điểm hình thái và khóa định loại cho các phân loài E. nipanicus dựa trên đặc điểm về màu sắc đã được trình bày. Đã ghi nhận các loài thuộc giống này có phân bố ở các tỉnh miền Bắc Việt Nam như Điện Biên, Lào Cai, Sơn La, Hòa Bình, Phú Thọ, Cao Bằng, Vĩnh Phúc, Hà Nội và Hà Tĩnh. Đây là kết quả nghiên cứu đầu tiên về phân loại của giống này ở Việt Nam, những ghi nhận về phân bố của giống này là đóng góp quan trọng cho nghiên cứu về mô hình phân bố của các loài thuộc giống này ở Châu Á.

Tù khóa: Vespidae, Eumeninae, Euodynerus, ghi nhận mới, Bắc Việt Nam.

Ngày nhận bài: 22-8-2012 